\title{
Effects of W and Mo Additions on Wet-dry Acid Corrosion Behavior of Low-Alloy Steels Under Different $\mathrm{O}_{2}$ Concentrations
}

\author{
Qing-He Zhao ${ }^{1} \cdot$ Wei Liu ${ }^{1} \cdot$ Shuan-Zhu Li ${ }^{1} \cdot$ Bin-Li Zhang ${ }^{1} \cdot$ Yi-Chun Zhu ${ }^{1} \cdot$ Min-Xu Lu ${ }^{1}$
}

Received: 12 April 2016/Revised: 31 May 2016/Published online: 17 August 2016

(C) The Chinese Society for Metals and Springer-Verlag Berlin Heidelberg 2016

\begin{abstract}
Effects of W and Mo additions on wet-dry acid corrosion behavior of low-alloy steels under different $\mathrm{O}_{2}$ concentrations were investigated. The results showed that $\mathrm{W}$ and Mo-containing steels presented excellent wet-dry corrosion resistance under $\mathrm{O}_{2}$ concentrations of both 1 and $5 \%$. The roles of $\mathrm{W}$ and Mo played in increasing corrosion resistance of the steels were different. W could improve the thermodynamic stability of the steel substrate, while Mo could promote the formation of protective rust. Interaction between $\mathrm{W}, \mathrm{Mo}$ and $\mathrm{O}_{2}$ concentration greatly influenced wet-dry acid corrosion of low-alloy steels. W addition was more effective for depressing charge transfer process at the rust/substrate interface and presented higher enhanced effect on increasing corrosion resistance than Mo under $\mathrm{O}_{2}$ concentration of $1 \%$. Mo was more effective on increasing rust compactness and showed higher enhanced effect on increasing corrosion resistance than $\mathrm{W}$ under $\mathrm{O}_{2}$ concentration of $5 \%$.
\end{abstract}

KEY WORDS: Wet-dry acid corrosion; Steel; Corrosion resistance; Electrochemical impedance spectroscopy (EIS); Rust

\section{Introduction}

$\mathrm{W}$ and Mo were two important alloying elements to increase corrosion resistance of the low-alloy steels. The effects of $\mathrm{W}$ and Mo have been reported in some corrosion environments, such as marine/industrial atmospheric corrosion, and sulfuric acid dew point corrosion environment [1-3]. Generally, under the above corrosion environments of wet-dry cyclic process, the dense protective rust could form on the steel surface to prevent corrosive species, such as $\mathrm{O}_{2}, \mathrm{SO}_{4}^{2-}, \mathrm{Cl}^{-},[1,2]$. W and Mo existed in the form of

Available online at http://link.springer.com/journal/40195

Wei Liu

weiliu@ustb.edu.cn

1 Corrosion and Protection Center, Institute for Advanced Materials and Technology, University of Science and Technology Beijing, Beijing 100083, China
$\mathrm{WO}_{4}^{2-}$ or $\mathrm{MoO}_{4}^{2-}$ ions in the rust, which changed the selective permeability from anion selectivity to cation selectivity, and therefore prevented the transportation of $\mathrm{SO}_{4}^{2-}$ and $\mathrm{Cl}^{-}$ions, and decreased corrosion rate of the steels [3]. Meanwhile, W and Mo could also form nonsoluble W (VI) and Mo (VI)-containing compounds in inner corrosion product, especially at the bottom of corrosion nest at the steel/rust interface, which inhibited corrosion of the steel $[3,4]$.

W and Mo were usually added to the steels in combination with certain content of $\mathrm{Cu}$ and $\mathrm{Cr}$ to improve corrosion resistance in $\mathrm{O}_{2}$-containing acid corrosion environment [5, 6]. Mo could form inclusions in the steels, such as $\mathrm{MoS}_{2}$, by which corrosion resistance of the steels was deteriorated, while $\mathrm{W}$ rarely formed inclusions [7, 8]. Park et al. [1] reported that the corrosion rate of $\mathrm{W}$ $(0.05 \mathrm{wt} \%)$ steel was lower than Mo $(0.05 \mathrm{wt} \%)$ steel in $10 \mathrm{wt} \%$ sulfuric acid solution, due to the relatively fewer type and quantity of inclusions in $\mathrm{W}$ steel $(\mathrm{MnS})$ than in 
Mo steel $\left(\mathrm{MnS}, \mathrm{MoS}_{2}\right)$. Moreover, $\mathrm{W}$ and Mo existing as solid solution state in the ferrite of steel could effectively improve acid corrosion resistance $[9,10]$. When $\mathrm{W}$ was added by more than $0.5 \%$ or Mo by more than $0.2 \%$, localized corrosion resistance of the steel was deteriorated rather than improved, as well as the weldability and toughness of the steel $[11,12]$.

Steels of the upper deck of cargo oil tanks of crude oil tankers suffered a special kind of wet-dry acid corrosion, which contained considerable amount of $\mathrm{O}_{2}, \mathrm{H}_{2} \mathrm{~S}$, and water vapor originated from crude oil, and condensed water with lower $\mathrm{pH}$ formed and appeared on the back side of upper deck due to the cyclic temperature change in day and night $[13,14]$. Such corrosion environment was different from the industrial/marine atmospheric corrosion and sulfuric acid dew point corrosion, due to the existence of $\mathrm{H}_{2} \mathrm{~S}$ and $\mathrm{O}_{2}$, and the concentration of $\mathrm{O}_{2}$ was usually controlled below 5\% [14-16]. The effects of $\mathrm{W}$ and Mo on corrosion resistance of the steels in some corrosion circumstances have been reported, but the effects of $\mathrm{W}$ and Mo were still unclear in wet-dry acid corrosion atmosphere containing $\mathrm{O}_{2}$ and $\mathrm{H}_{2} \mathrm{~S}$. The aim of the present research is to compare the effects of $\mathrm{W}$ and Mo on wet-dry acid corrosion of the steel under different $\mathrm{O}_{2}$ concentrations by corrosion loss, corrosion morphologies, rust compositions and structures as well as electrochemical measurements.

\section{Experimental}

\subsection{Tested Steels}

Table 1 shows the chemical composition of the tested steels. Steels were prepared by melting the constituent elements in a vacuum induction furnace and then were casted into slabs. The slabs were reheated at $1200{ }^{\circ} \mathrm{C}$ for $2 \mathrm{~h}$ and then hotrolled into the plates with a thickness of $18 \mathrm{~mm}$. The size of the specimens was $60 \mathrm{~mm} \times 25 \mathrm{~mm} \times 5 \mathrm{~mm}$ for the measurement of corrosion loss, and $10 \mathrm{~mm} \times 10 \mathrm{~mm} \times$ $5 \mathrm{~mm}$ for rust analysis, respectively. Specimens were grounded gradually down to $800 \#$ grade with $\mathrm{SiC}$ paper, cleaned with acetone and ethanol, and then stored in a desiccator for $24 \mathrm{~h}$. The tested specimens were weighed on an electronic balance with accuracy of $0.1 \mathrm{mg}$, and the width and length of exposure surface of the specimens were measured by vernier caliper with accuracy of $0.02 \mathrm{~mm}$. Before corrosion tests, the tested specimens were sealed by silica gel with exposure area of $15 \mathrm{~cm}^{2}$ for weight loss measurements and $1 \mathrm{~cm}^{2}$ for electrochemical measurements, respectively.

\subsection{Corrosion Test}

Figure 1 shows the schematic of wet-dry acid corrosion test device. The specimens were fixed on back of top cover of the experimental device, and the temperature of specimens was controlled by controlling temperature of top cover. The temperature of the specimens was controlled at $25^{\circ} \mathrm{C}$ for $3 \mathrm{~h}, 50{ }^{\circ} \mathrm{C}$ for $7 \mathrm{~h}$, the transition time between 25 and $50{ }^{\circ} \mathrm{C}$ was $1 \mathrm{~h}$, and one wet-dry corrosion cycle time (CCT) was $12 \mathrm{~h}$. The temperature of distilled water was between 30 and $32{ }^{\circ} \mathrm{C}$. When the specimens were controlled at $25^{\circ} \mathrm{C}$, condensate water could form on the specimen surface, and when the specimens were controlled at $50{ }^{\circ} \mathrm{C}$, the condensate water could evaporate. Thus, the wet-dry process of the specimen surface could be simulated. The gas composition in simulated wet-dry acid corrosion consisted of: a) $\mathrm{O}_{2} \quad 1 \%-\mathrm{H}_{2} \mathrm{~S} \quad 500 \mathrm{ppm}-\mathrm{SO}_{2}$ $100 \mathrm{ppm}-\mathrm{CO}_{2} \quad 13 \%-\mathrm{N}_{2}$ balance; and b) $\mathrm{O}_{2} 5 \%-\mathrm{H}_{2} \mathrm{~S}$ $500 \mathrm{ppm}-\mathrm{SO}_{2} 100 \mathrm{ppm}-\mathrm{CO}_{2} 13 \%-\mathrm{N}_{2}$ balance, to illustrate acid corrosion behavior of the steels under different $\mathrm{O}_{2}$ concentrations. Before experiment, $\mathrm{N}_{2}$ was inlet into the device with gas flow rate larger than $500 \mathrm{~mL} / \mathrm{min}$, to clear $\mathrm{O}_{2}$ inside the device. Then, the mixed gas was inlet into the device. The minimum gas flow rate was $100 \mathrm{~mL} / \mathrm{min}$ for first $24 \mathrm{~h}$, and then $20 \mathrm{~mL} / \mathrm{min}$ after $24 \mathrm{~h}$. Distance between the specimen surface and distilled water was $180 \mathrm{~mm}$, avoiding the splash of distilled water. Thus, the wet-dry acid corrosion of the steels could be simulated.

Rusts formed after different corrosion times were removed using blade and pickling solution $(\mathrm{HCl}$ $500 \mathrm{~mL}+\mathrm{H}_{2} \mathrm{O} 500 \mathrm{~mL}+\mathrm{C}_{6} \mathrm{H}_{12} \mathrm{~N}_{4} 3.5 \mathrm{~g}$ ) in accordance with standard ASTM G1-03 [17], and then the specimens were cleaned and dried in ethanol, weighed on an electric balance with accuracy of $0.1 \mathrm{mg}$. Corrosion loss of the specimens was calculated by formula 1 :

$C_{\mathrm{L}}=\frac{W_{0}-W_{1}}{S \times \rho}$

Table 1 Chemical composition of tested steels (wt $\%$ )

\begin{tabular}{llllllllllll}
\hline Steels & $\mathrm{C}$ & $\mathrm{Si}$ & $\mathrm{Mn}$ & $\mathrm{S}$ & $\mathrm{P}$ & $\mathrm{Cu}$ & $\mathrm{Ni}$ & $\mathrm{Cr}$ & $\mathrm{Mo}$ & $\mathrm{W}$ & $\mathrm{Fe}$ \\
\hline Blank steel & 0.08 & 0.24 & 1.09 & 0.002 & 0.01 & 0.28 & 0.20 & 0.17 & - & - & Bal. \\
W steel & 0.08 & 0.24 & 1.05 & 0.002 & 0.01 & 0.27 & 0.19 & 0.18 & - & 0.22 & Bal. \\
Mo steel & 0.07 & 0.24 & 1.04 & 0.002 & 0.01 & 0.28 & 0.20 & 0.17 & 0.25 & - & Bal. \\
\hline
\end{tabular}




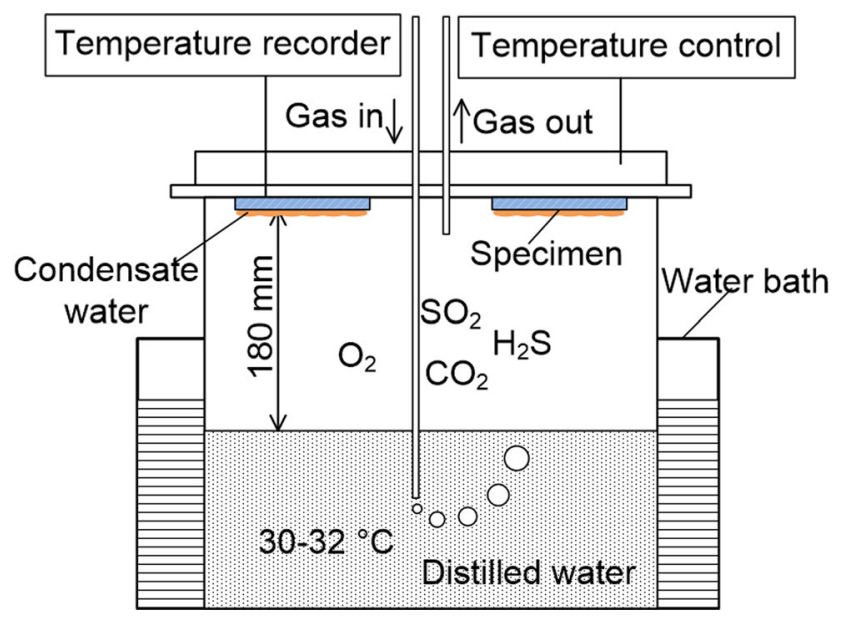

Fig. 1 Schematic of wet-dry acid corrosion test device

where $C_{\mathrm{L}}$ was corrosion loss $(\mu \mathrm{m}) ; W_{0}$ was specimen weight before corrosion $(\mathrm{g}) ; W_{1}$ was specimen weight after corrosion $(\mathrm{g}) ; S$ was corrosion area $\left(\mathrm{cm}^{2}\right)$; and $\rho$ was the density of tested steels $\left(7.85 \mathrm{~g} / \mathrm{cm}^{3}\right)$.

\subsection{Rust Analyses}

The microstructures of bare steels and cross-sectional morphologies of rusted steels were observed by SEM. Rust was stripped mechanically using blade and carefully collected. Rust powder was prepared for quantitative phase analysis using XRD method. $\mathrm{ZnO}$ was used as internal standard for quantitative analyses of rust composition, and $\mathrm{ZnO} /$ rust ratio was 1:9 $[18,19]$. Crystalline rust phases contained $\alpha-\mathrm{FeOOH}, \gamma$-FeOOH, $\mathrm{Fe}_{3} \mathrm{O}_{4}, \mathrm{Fe}_{x} \mathrm{~S}_{y}$ and $\mathrm{S}$. The diffraction intensities of (011) reflection of $\alpha-\mathrm{FeOOH}$, (020) reflection of $\gamma$-FeOOH, (220) reflection of $\mathrm{Fe}_{3} \mathrm{O}_{4}$, (331) reflection of $\mathrm{Fe}_{x} \mathrm{~S}_{y}$ and (220) reflection of $S$ were measured and compared with (100) reflection of $\mathrm{ZnO}$. Thus, the content of crystalline rust phases could be obtained, and the amorphous phase was balance. Specific surface area $(S S A)$ of the rust was measured using $N_{2}$ adsorption and calculated by BET equation.

\subsection{Electrochemical Measurements}

Potentiodynamic polarization curves and electrochemical impedance spectroscopy (EIS) of the bare and rusted steels were measured using a three-electrode system and an electrochemical work station. All specimens for electrochemical test were enclosed with epoxy resin with an exposed area of $1 \mathrm{~cm}^{2}$. The working electrode was the bare and rusted steels, the reference electrode was a saturated calomel electrode, and the auxiliary electrode was a platinum electrode. The test electrolyte was $0.01 \mathrm{M} \mathrm{Na}_{2} \mathrm{SO}_{4}$ solution, with $\mathrm{pH} 3.0$ and at temperature of $25^{\circ} \mathrm{C}$. The corresponding mixed gas composing of $\mathrm{O}_{2}, \mathrm{H}_{2} \mathrm{~S}, \mathrm{SO}_{2}, \mathrm{CO}_{2}$ and $\mathrm{N}_{2}$ was inlet into test electrolyte with minimum gas flow rate of $100 \mathrm{~mL} / \mathrm{min}$ for $1 \mathrm{~h}$ before electrochemical tests. For measurements of potentiodynamic polarization curves of the steels, the polarization potential was swept from $-0.4 \mathrm{~V}$ to $1.6 \mathrm{~V}$ vs. open circuit potential (OCP) with scan rate of $0.5 \mathrm{mV} / \mathrm{s}$. For EIS measurements, the frequency ranged from $100 \mathrm{kHz}$ to $10 \mathrm{mHz}$, and the signal amplitude was $5 \mathrm{mV}$. The measured EIS plots were calculated using ZSimpWin software.

\section{Results}

\subsection{Microstructure of Steels}

Figure 2 gives the microstructure of the tested steels. The results indicate that the microstructures of the steels were all mainly composed of the ferrite and small amount of pearlite, which distributed on the grain boundaries of ferrite. $\mathrm{W}$ and Mo-containing steel had lower content of the pearlite in fraction comparing with blank steel, indicating that $\mathrm{W}$ and $\mathrm{Mo}$ additions could reduce the formation of the pearlite in the steel. The grain size of the ferrite in $\mathrm{W}$ and Mo-containing steels was smaller than that of blank steel, indicating that $\mathrm{W}$ and Mo additions could depress the growth of the ferrite during rolling process. Meanwhile, W steel had smaller content of pearlite than Mo steel, and Mo steel presented finer grain size of ferrite than $\mathrm{W}$ steel. The inclusions were rarely observed in $\mathrm{W}$ and Mo-containing steels due to low contents of carbon and sulfur in the steels, and W and Mo mainly existed in a form of solid solution in the ferrite of tested steels.

\subsection{Corrosion Kinetics}

Figure $3 \mathrm{a}$ shows that corrosion loss of the steels with increasing corrosion time under $\mathrm{O}_{2}$ concentration of $1 \%$, and corrosion loss at $42 \mathrm{CCT}$ decreased in the following order: blank steel $>$ Mo steel $>$ W steel. The results indicated that $\mathrm{W}$ and Mo additions could obviously decrease corrosion loss of the steels under concentration of $1 \%$, and the decreasing effect of $\mathrm{W}$ was higher than that of Mo. Figure $3 b$ shows that corrosion loss of the steels under $\mathrm{O}_{2}$ concentration of $5 \%$ was much higher than that of $1 \%$, which indicated that the increased $\mathrm{O}_{2}$ concentration made wet-dry acid corrosion more severe. Meanwhile, corrosion loss at $42 \mathrm{CCT}$ is given as: blank steel $>\mathrm{W}$ steel $>$ Mo steel. The results indicated that $\mathrm{W}$ and Mo additions could decrease the corrosion loss of the steels under $\mathrm{O}_{2}$ concentration of $5 \%$, and the decreasing effect of Mo was better than that of $\mathrm{W}$. Therefore, both $\mathrm{W}$ and Mo could decrease the corrosion loss of low-alloy steels, and the enhanced effects of $\mathrm{W}$ and Mo were different. 

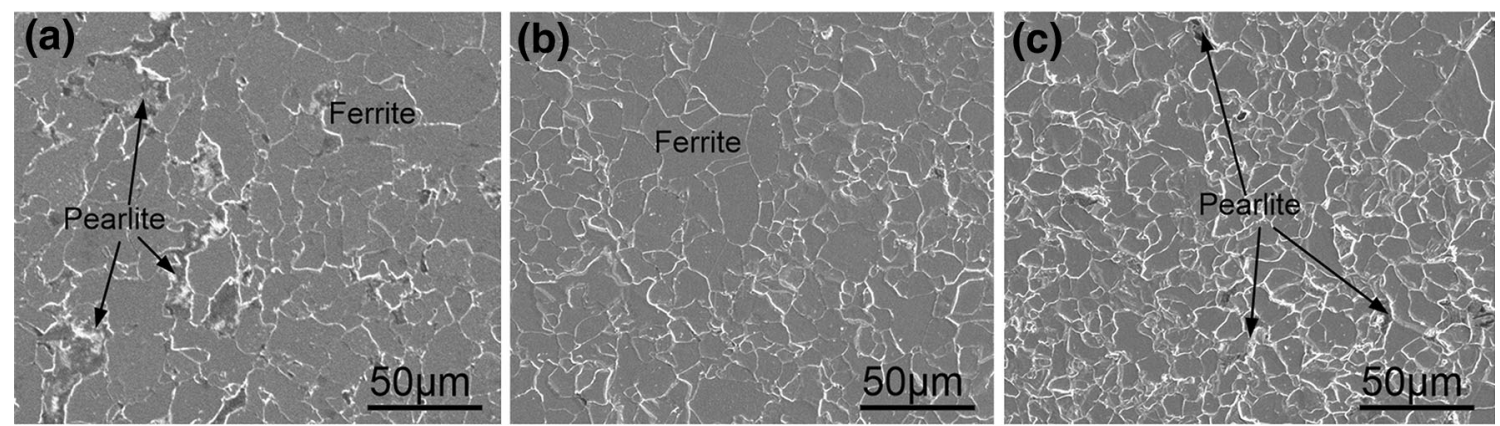

Fig. 2 SEM micrographs of the bare steels: a blank steel; b W steel; c Mo steel
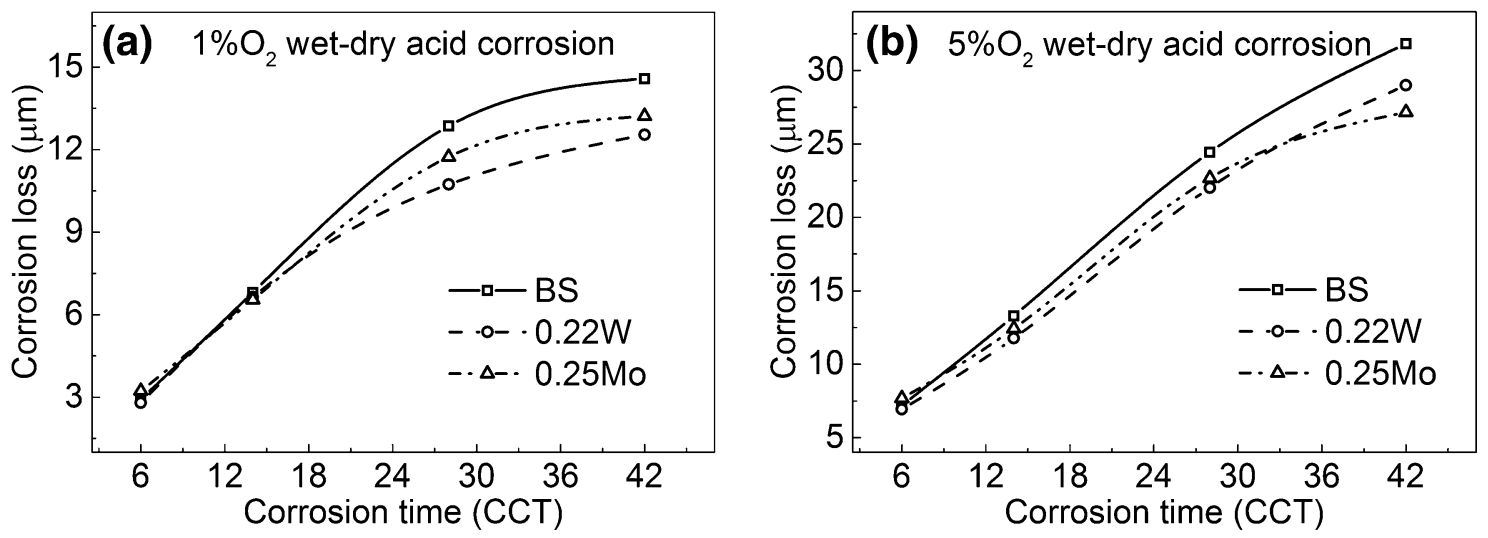

Fig. 3 Corrosion loss of the steels in wet-dry acid corrosion environments with different $\mathrm{O}_{2}$ concentrations of a $1 \%$; b 5\%

\subsection{Electrochemical Measurements}

Figure 4 shows potentiodynamic polarization curves of the bare steels in $0.01 \mathrm{M} \mathrm{Na}_{2} \mathrm{SO}_{4}$ solution with $\mathrm{pH} 3.0$ and at temperature of $25{ }^{\circ} \mathrm{C}$. The results indicated that the cathodic polarization behaviors of the tested steels were nearly the same, while the anodic polarization behaviors were different. Cathodic polarization behavior of the bare

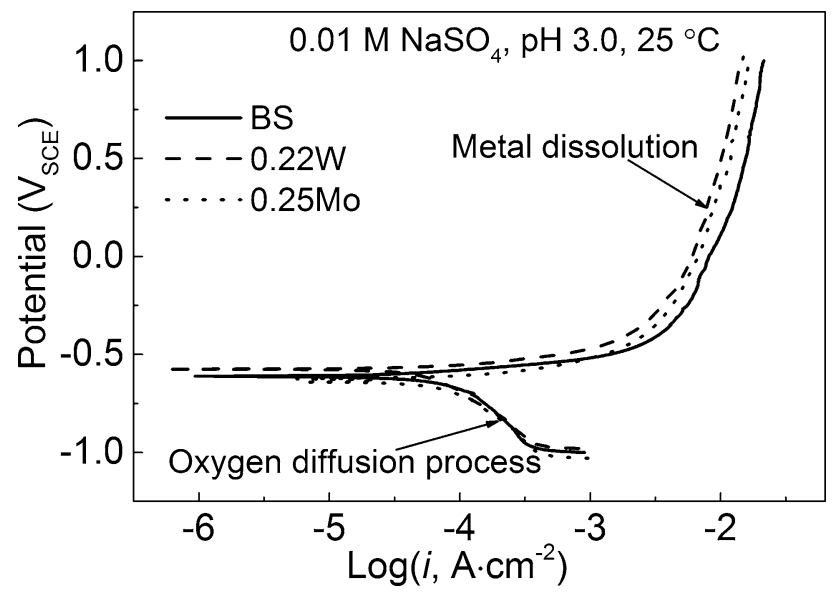

Fig. 4 Potentiodynamic polarization curves of the bare steels in $0.01 \mathrm{M} \mathrm{Na}_{2} \mathrm{SO}_{4}$ solution with $\mathrm{pH} 3.0$ and at temperature of $25{ }^{\circ} \mathrm{C}$ steels was mainly influenced by acid electrolyte, while anodic polarization behavior of the bare steels was mainly affected by alloying elements in the steels [20,21]. W and Mo additions could obviously reduce anodic current density of the bare steels when polarization potential was more positive than $-0.35 \mathrm{~V}_{\mathrm{SCE}}$, and reducing effect of $\mathrm{W}$ was better than that of Mo, indicating that $\mathrm{W}$ had higher enhanced effect on depressing dissolution process of the steels under strongly polarizing condition.

Table 2 gives the fitted parameters of potentiodynamic polarization curves in Fig. 4. The results showed that the corrosion current density $i_{\text {corr }}$ of $\mathrm{W}$ steel was lower than that of blank steel, while $i_{\text {corr }}$ of Mo steel was higher than that of the blank steel, indicating that $\mathrm{W}$ could reduce and Mo could accelerate the dissolution process of the bare steels in acid electrolyte. Corrosion potential $E_{\text {corr }}$ of W steel was more positive, while $E_{\text {corr }}$ of Mo steel was more negative than that of blank steel, which indicated that $\mathrm{W}$ could increase thermodynamic stability of steel in acid electrolyte, and Mo presented an opposite effect. The above difference of corrosion current $i_{\text {corr }}$ and corrosion potential $E_{\text {corr }}$ of three bare steels which was related to the enhanced effect of elements $\mathrm{W}$ and Mo might contribute to the different corrosion performances in wet-dry acid corrosion. 
Table 2 Fitted parameters for potentiodynamic polarization curves of the bare steels

\begin{tabular}{llccc}
\hline Steels & $E_{\text {corr }}\left(\mathrm{mV}_{\mathrm{SCE}}\right)$ & $i_{\text {corr }}\left(\mu \mathrm{A} \mathrm{cm}{ }^{-2}\right)$ & $\beta_{\mathrm{a}}(\mathrm{mV} / \mathrm{dec})$ & $\beta_{\mathrm{c}}(\mathrm{mV} / \mathrm{dec})$ \\
\hline Blank steel & -612 & 84.3 & 25.4 & 265.4 \\
W steel & -587 & 73.1 & 22.6 & 249.1 \\
Mo steel & -630 & 103.1 & 27.3 & 292.3 \\
\hline
\end{tabular}

Figure 5 shows the EIS plots of the bare steels. Bode plots showed one time constant in middle frequency region, which was related to charge transfer resistance $\left(R_{\mathrm{ct}}\right)$. Inductance was also observed in low-frequency region due to the uneven adsorption of $\mathrm{FeOH}^{+}$on steel surface $[22,23]$. Figure 6 shows the equivalent circuit for fitting EIS plots of bare steels. $R_{\mathrm{S}}$ is the resistance of test electrolyte. $Q_{\mathrm{dl}}$ is the capacitance of electric double layer, and $R_{\mathrm{ct}}$ is the charge transfer resistance. $R_{\mathrm{L}}$ is the inductance resistance, and $L$ is the inductance element. Table 3 shows the fitted parameters of measured EIS plots using the equivalent circuit. The results showed that $R_{\mathrm{ct}}$ of bare W steel was higher than that of the blank steel, and $R_{\mathrm{ct}}$ of Mo steel was lower than that of blank steel, which indicated that $\mathrm{W}$ could increase, while Mo could decrease corrosion resistance of the steel in acid electrolyte, which were correspondent to $i_{\text {corr }}$ in Table 2 .

Figure 7 shows the EIS plots of the rusted steels under $\mathrm{O}_{2}$ concentration of $1 \%$. Figure $7 \mathrm{a}, \mathrm{c}$ and e indicates that all Nyquist plots of the rusted steels consist of two depressed semicircles in high- and low-frequency regions. Figure $7 \mathrm{~b}, \mathrm{~d}$ and $\mathrm{f}$ indicates that all Bode plots of rusted steels show two time constants in high- and low-frequency region. The semicircles in high-frequency regions of Nyquist plots were related to rust resistance $\left(R_{\text {rust }}\right)$, and the semicircles in low-frequency regions of Nyquist plots reflected charge transfer resistance $\left(R_{\mathrm{ct}}\right)$. Figure 8 shows the equivalent circuit for fitting EIS plots of the rusted steels [24]. $Q_{\text {rust }}$ is the rust capacitance, and $R_{\text {rust }}$ is the rust

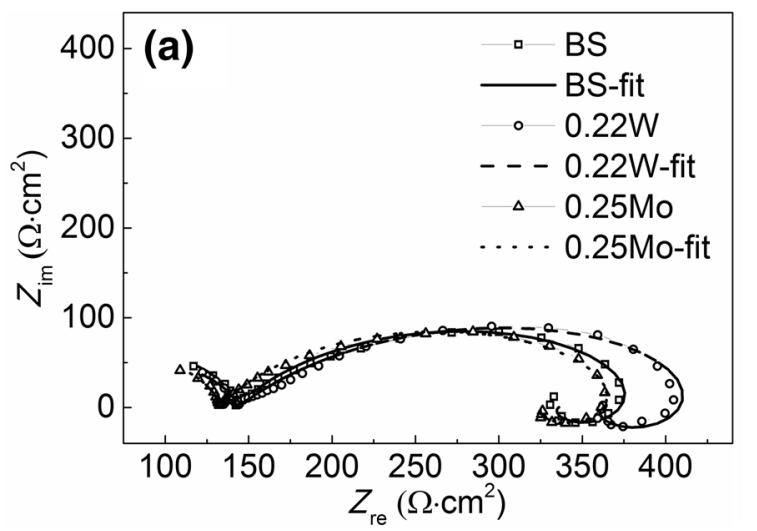

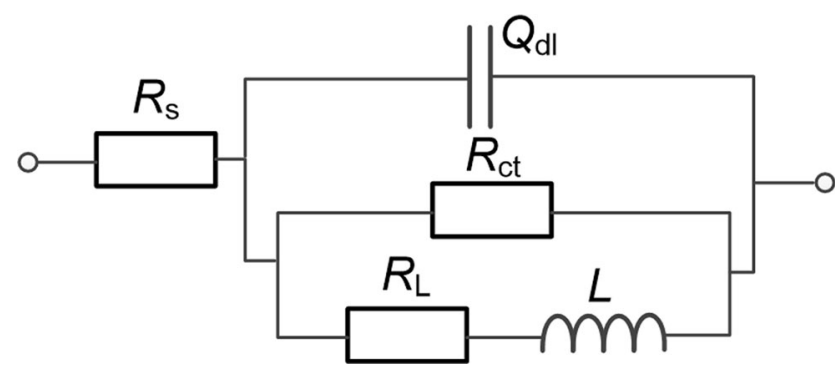

Fig. 6 Equivalent circuit for fitting EIS plots of the bare steels tested

resistance. $Q_{\mathrm{dl}}$ is the capacitance of electric double layer, and $R_{\mathrm{ct}}$ is the charge transfer resistance. $W$ is the Warburg impedance, which is related to diffusion of corrosive species in rust.

Table 4 gives the fitted electrochemical parameters from EIS plots of the rusted steels under $\mathrm{O}_{2}$ concentration of $1 \%$. The results indicated that $R_{\text {rust }}$ and $R_{\mathrm{ct}}$ of the rusted steels increased with increasing corrosion time. $R_{\text {rust }}$ of the blank steel increased from 111.3 to $163.8 \Omega \mathrm{cm}^{2}, R_{\text {rust }}$ of W steel increased from 108.8 to $156.9 \Omega \mathrm{cm}^{2}$, and $R_{\text {rust }}$ of Mo steel increased from 126.1 to $178.5 \Omega \mathrm{cm}^{2}$. Meanwhile, $R_{\mathrm{ct}}$ of the blank steel increased from 292.9 to $306.7 \Omega \mathrm{cm}^{2}, R_{\mathrm{ct}}$ of W steel increased from 348.8 to $469.6 \Omega \mathrm{cm}^{2}$, and $R_{\mathrm{ct}}$ of Mo steel increased from 283.4 to $399.3 \Omega \mathrm{cm}^{2}$. The results showed that $R_{\mathrm{ct}}$ presented obvious difference, while $R_{\text {rust }}$ presented little difference among the rusted steels, which indicated that $\mathrm{W}$ and Mo additions could depress the charge transfer process of the rusted steels to obtain higher



Fig. 5 EIS plots of the bare steels tested in $0.01 \mathrm{M} \mathrm{Na}_{2} \mathrm{SO}_{4}$ solution with $\mathrm{pH} 3.0$ and at temperature of $25^{\circ} \mathrm{C}$ 
Table 3 Fitted parameters of EIS plots of bare steels in acid electrolyte

\begin{tabular}{llllll}
\hline Steels & $Q_{\mathrm{dl}}\left(\mathrm{F} \mathrm{cm}^{-2}\right)$ & $n_{\mathrm{dl}}$ & $R_{\mathrm{ct}}\left(\Omega \mathrm{cm}^{2}\right)$ & $R_{\mathrm{L}}\left(\Omega \mathrm{cm}^{2}\right)$ & 32.4 \\
Blank steel & $1.23 \mathrm{E}-08$ & 0.938 & 142.3 & 23.5 & 247.8 \\
W steel & $3.87 \mathrm{E}-08$ & 0.836 & 149.1 & 42.7 & 161.7 \\
Mo steel & $1.51 \mathrm{E}-08$ & 0.927 & 132.6 & 378.5 \\
\hline
\end{tabular}
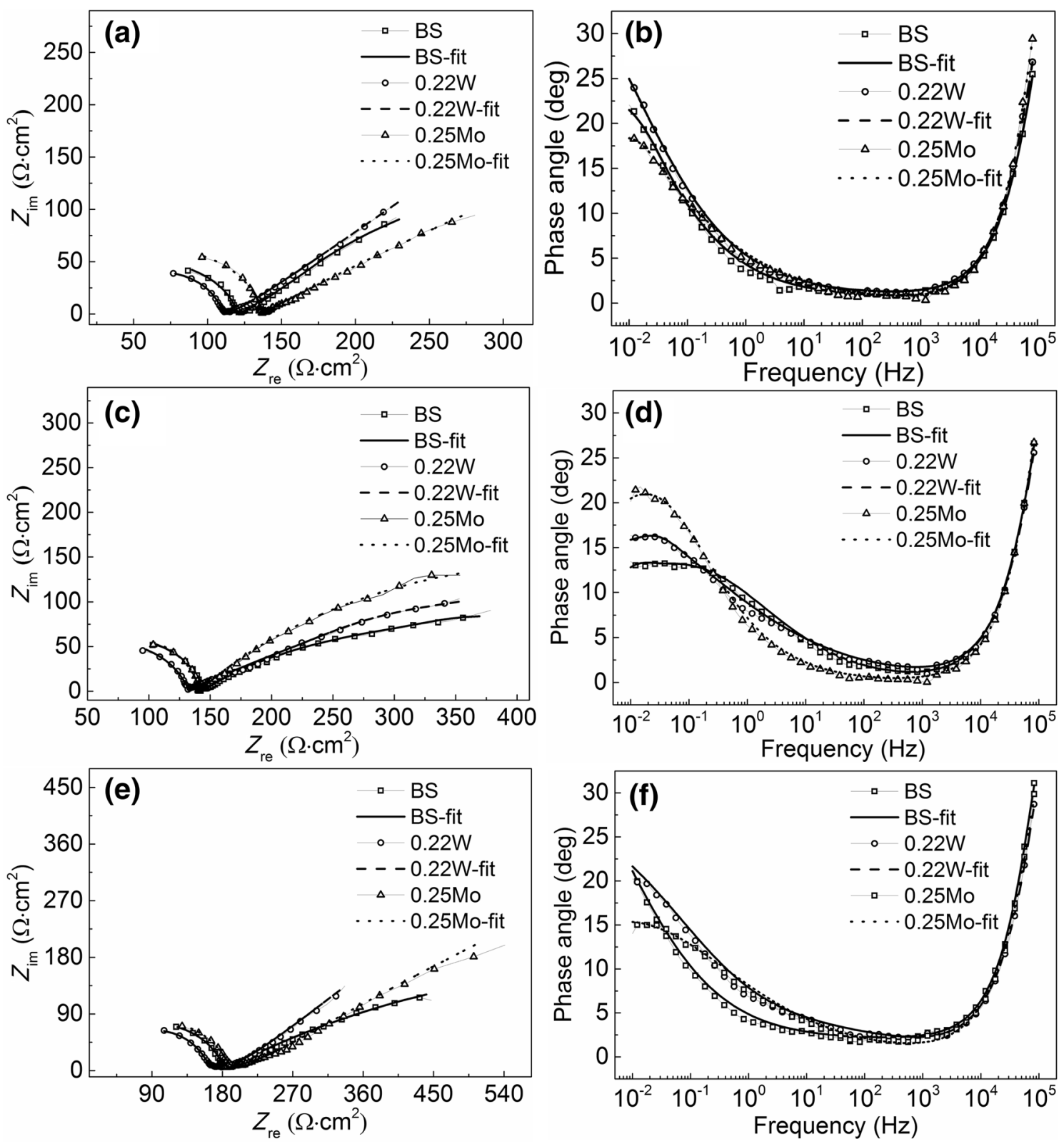

Fig. 7 EIS plots of rusted steels in $1 \% \mathrm{O}_{2}$ wet-dry acid corrosion: a, b 14 CCT; c, d 28 CCT; e, f 42 CCT

corrosion resistance. W steel presented the largest $R_{\mathrm{ct}}$ among the steels during corrosion process. $R_{\mathrm{ct}}$ of Mo steel showed little difference in first $28 \mathrm{CCT}$, and obvious increase at 42 CCT comparing with that of the blank steel. The results indicated that both $\mathrm{W}$ and Mo addition could increase $R_{c t}$ of the steels, and W had higher enhanced effect than Mo under $\mathrm{O}_{2}$ concentration of $1 \%$.

Figure 9 gives the EIS plots of the rusted steels under $\mathrm{O}_{2}$ concentration of 5\%. Nyquist plots of the rusted steels were all composed of two depressed semicircles, as shown in 


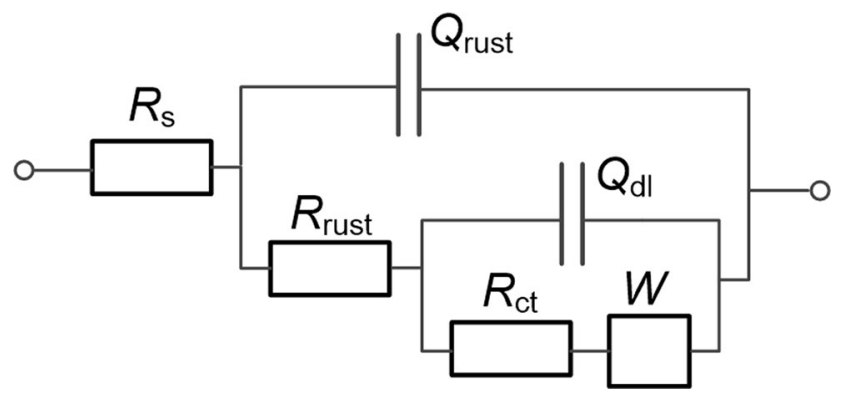

Fig. 8 Equivalent circuit for fitting EIS plots of rusted steels

Fig. 9a, c and e. Meanwhile, Bode plots of the rusted steels showed two time constants in high- and low-frequency region, as shown in Fig. 9b, $\mathrm{d}$ and $\mathrm{f}$. Time constant in highfrequency region was related to the rust resistance $R_{\text {rust }}$, and time constant in low-frequency region reflected the charge transfer resistance $R_{\mathrm{ct}}$. Phase angle of time constant in low-frequency region decreased with increasing corrosion time, which was different from that under $\mathrm{O}_{2}$ concentration of $1 \%$. The difference of Bode plots under $\mathrm{O}_{2}$ concentrations of $1 \%$ and $5 \%$ might be caused by the different characteristics of the rusts. EIS plots in Fig. 9 could also be fitted by the equivalent circuit shown in Fig. 8 .

Table 5 shows the fitted electrochemical parameters under $\mathrm{O}_{2}$ concentration of $5 \%$. The results showed that $R_{\text {rust }}$ of the blank steel increased from 76.7 to $232.3 \Omega \mathrm{cm}^{2}, R_{\text {rust }}$ of W steel increased from 128.6 to $303.7 \Omega \mathrm{cm}^{2}$, and $R_{\text {rust }}$ of Mo steel increased from 214.4 to $475.1 \Omega \mathrm{cm}^{2}$. Meanwhile, $R_{\text {ct }}$ of the blank steel increased from 296.2 to $501.3 \Omega \mathrm{cm}^{2}, R_{\mathrm{ct}}$ of W steel increased from 329.1 to $556.6 \Omega \mathrm{cm}^{2}$, and $R_{\mathrm{ct}}$ of Mo steel increased from 249.8 to $678.5 \Omega \mathrm{cm}^{2}$. It could be seen that both $R_{\text {rust }}$ and $R_{\mathrm{ct}}$ of the rusted steels increased obviously with increasing corrosion time under $\mathrm{O}_{2}$ concentration of $5 \%$, which was different from that under $\mathrm{O}_{2}$ concentration of $1 \%$. W and Mo additions could increase $R_{\text {rust }}$ and $R_{\mathrm{ct}}$ of the rusted steels, and the enhanced effect of Mo was better than that of W.

\subsection{Rust Analysis}

Tables 6 and 7 give the phase composition of the rusts at $42 \mathrm{CCT}$ under $\mathrm{O}_{2}$ concentrations of 1 and $5 \%$, respectively. The results indicated that the rust formed in wet-dry acid corrosion was mainly composed of amorphous phase, $\gamma$ $\mathrm{FeOOH}, \alpha-\mathrm{FeOOH}, \mathrm{Fe}_{x} \mathrm{~S}_{y}, \mathrm{~S}$ and $\mathrm{Fe}_{3} \mathrm{O}_{4}$. The content of the crystalline phases in the rust including $\gamma-\mathrm{FeOOH}, \alpha$ $\mathrm{FeOOH}, \mathrm{Fe}_{x} \mathrm{~S}_{y}, \mathrm{~S}$ and $\mathrm{Fe}_{3} \mathrm{O}_{4}$ decreased, while the content of amorphous phase increased with increasing $\mathrm{O}_{2}$ concentration. Higher $\mathrm{O}_{2}$ concentration in wet-dry acid corrosion promoted the formation of amorphous phase, which was the main component of dense and protective rust [25]. Thus, the rust formed under $\mathrm{O}_{2}$ concentration of $5 \%$ presented higher $R_{\text {rust }}$ than that under $\mathrm{O}_{2}$ concentration of $1 \%$. The different rust compositions under $\mathrm{O}_{2}$ concentrations of 1 and 5\% changed the characteristic of the rust, as well as the roles $\mathrm{W}$ and Mo played in corrosion resistance of the rusted steels.

Figure 10 gives specific surface area (SSA) of the rust at $42 \mathrm{CCT}$ under $\mathrm{O}_{2}$ concentrations of 1 and $5 \%$. SSA of the rust was an important parameter for evaluation of barrier effect to corrosive species $[25,26]$. The rust with higher SSA presented higher barrier effect to corrosive species. The results indicated that the rust formed under $\mathrm{O}_{2}$ concentration of $5 \%$ presented higher SSA than that under $\mathrm{O}_{2}$ concentration of $1 \%$. Higher $\mathrm{O}_{2}$ concentration greatly increased SSA of the rust due to the increasing content of amorphous phase, which was the main component of dense and protective rust $[26,27]$. The roles $\mathrm{W}$ and Mo played in SSA of the rust were different and were greatly influenced by $\mathrm{O}_{2}$ concentration. Under $\mathrm{O}_{2}$ concentration of $1 \%, \mathrm{~W}$ addition slightly decreased SSA of the rust, and Mo slightly increased SSA of the rust. However, under $\mathrm{O}_{2}$ concentration of $5 \%$, both $\mathrm{W}$ and Mo obviously increased SSA of the rust, and the enhanced effect of Mo was higher than that of $\mathrm{W}$.

Figure 11 shows cross-sectional morphologies of the rust formed on the three tested steels at $42 \mathrm{CCT}$ under $\mathrm{O}_{2}$ concentrations of both $1 \%$ and $5 \%$. The rust formed under

Table 4 Fitted parameters of EIS plots for the rusted steels in $1 \% \mathrm{O}_{2}$ wet-dry acid corrosion

\begin{tabular}{lllllllll}
\hline Steels & CCT & $Q_{\text {rust }}\left(\mathrm{F} \mathrm{cm}^{-2}\right)$ & $n_{\text {rust }}$ & $R_{\text {rust }}\left(\Omega \mathrm{cm}^{2}\right)$ & $Q_{\mathrm{dl}}\left(\mathrm{F} \mathrm{cm}^{-2}\right)$ & $n_{\mathrm{dl}}$ & $R_{\mathrm{ct}}\left(\Omega \mathrm{cm}^{2}\right)$ & $W\left(\Omega \mathrm{cm}^{2}\right)$ \\
\hline Blank steel & 14 & $1.71 \mathrm{E}-07$ & 0.987 & 111.3 & 0.0011 & 0.151 & 292.9 \\
& 28 & $2.56 \mathrm{E}-08$ & 0.938 & 130.9 & 0.00502 & 0.118 & 289.8 & 0.0255 \\
& 42 & $3.17 \mathrm{E}-08$ & 0.884 & 163.8 & 0.00802 & 0.348 & 306.7 & 0.0508 \\
W steel & 14 & $9.04 \mathrm{E}-08$ & 0.974 & 108.8 & 0.00254 & 0.173 & 348.8 & 0.0957 \\
& 28 & $3.88 \mathrm{E}-08$ & 0.893 & 130.6 & 0.0119 & 0.336 & 376.2 & 0.0268 \\
& 42 & $1.97 \mathrm{E}-08$ & 0.962 & 156.9 & 0.00548 & 0.125 & 469.6 & 0.0744 \\
Mo steel & 14 & $1.59 \mathrm{E}-07$ & 0.953 & 126.1 & 0.00122 & 0.135 & 283.4 & 0.0297 \\
& 28 & $1.94 \mathrm{E}-08$ & 0.941 & 128.5 & 0.0155 & 0.265 & 298.6 & 0.0442 \\
& 42 & $6.31 \mathrm{E}-08$ & 0.851 & 178.5 & 0.0111 & 0.404 & 399.3 \\
\hline
\end{tabular}



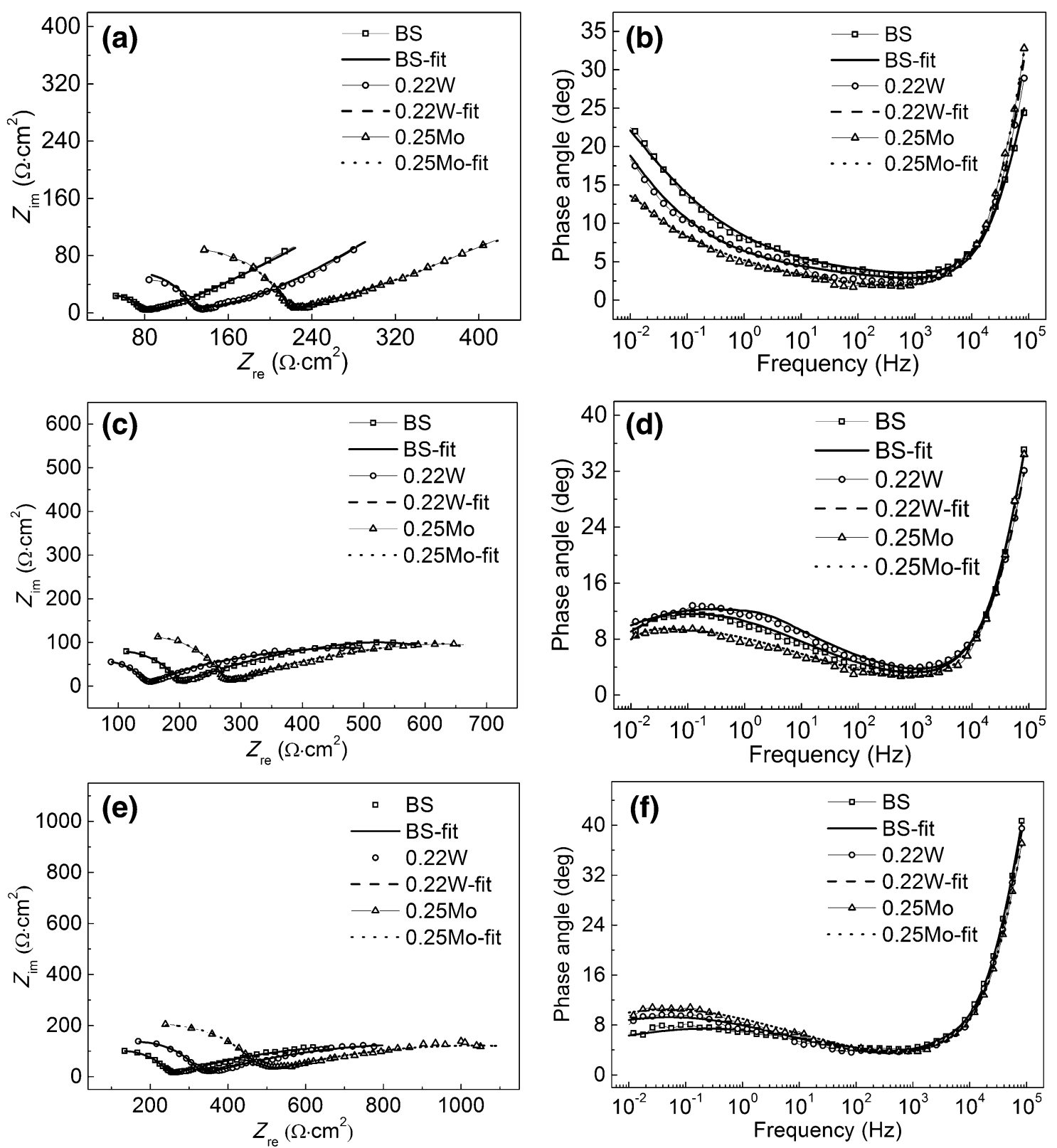

Fig. 9 EIS plots of the rusted steels in 5\% $\mathrm{O}_{2}$ wet-dry acid corrosion: a, b 14 CCT; c, d 28 CCT; e, f 42 CCT

$1 \% \mathrm{O}_{2}$ presented higher rust thickness and obvious doublelayer structure comparing with that under $\mathrm{O}_{2}$ concentration of $5 \%$, which indicated that higher $\mathrm{O}_{2}$ concentration contributed to the formation of thinner and compacter rust, and was corresponding to the results shown in Fig. 10.

Figure $11 \mathrm{a}, \mathrm{b}$ and $\mathrm{c}$ shows the cross-sectional morphologies of the rust under $\mathrm{O}_{2}$ concentration of $1 \%$. Figure $11 \mathrm{a}$ presents large cracks inside rust of the blank steel, and the inner layer of the rust was loose and less protective. Figure $11 \mathrm{~b}$ and $\mathrm{c}$ shows much compacter rust of $\mathrm{W}$ steel and Mo steel, and the rust/substrate interface was more even, comparing with that of the blank steel. Meanwhile, the rust of $\mathrm{W}$ steel presented single-layer structure, and the highest rust compactness among three steels.

Figure 11d, e and f shows the cross-sectional morphologies of the rusts under $\mathrm{O}_{2}$ concentration of $5 \%$. Figure $11 \mathrm{~d}$ presents obvious and continuous cracks inside the rust of the blank steel. Figure 11e and f shows that the rust of $\mathrm{W}$ steel and Mo steel was compacter and thicker, and the rust/substrate interface was more even than that of the blank steel, which indicated that $\mathrm{W}$ and Mo could reduce the selective corrosion of the steel. Moreover, some tiny cracks could also be seen in the rusts of W steel and Mo steel, and the rust of Mo steel was compacter than that of $\mathrm{W}$ steel. 
Table 5 Fitted parameters of EIS plots for the rusted steels in $5 \% \mathrm{O}_{2}$ wet-dry acid corrosion

\begin{tabular}{lllllllll}
\hline Steels & CCT & $Q_{\text {rust }}\left(\mathrm{F} \mathrm{cm}^{-2}\right)$ & $n_{\text {rust }}$ & $R_{\text {rust }}\left(\Omega \mathrm{cm}^{2}\right)$ & $Q_{\mathrm{dl}}\left(\mathrm{F} \mathrm{cm}^{-2}\right)$ & $n_{\mathrm{dl}}$ & $R_{\mathrm{ct}}\left(\Omega \mathrm{cm}^{2}\right)$ & $W\left(\Omega \mathrm{cm}^{2}\right)$ \\
\hline Blank steel & 14 & $3.33 \mathrm{E}-08$ & 0.764 & 76.7 & 0.00762 & 0.342 & 296.2 & 0.0142 \\
& 28 & $3.83 \mathrm{E}-08$ & 0.884 & 189.3 & 0.00304 & 0.334 & 340.4 & - \\
& 42 & $3.65 \mathrm{E}-08$ & 0.88 & 232.3 & 0.00302 & 0.269 & 501.3 & - \\
W steel & 14 & $8.61 \mathrm{E}-08$ & 0.835 & 128.6 & 0.00701 & 0.359 & 329.1 & 0.0168 \\
& 28 & $6.74 \mathrm{E}-08$ & 0.857 & 139.4 & 0.00298 & 0.353 & 468.2 & - \\
& 42 & $2.48 \mathrm{E}-08$ & 0.894 & 303.7 & 0.00262 & 0.249 & 556.6 & - \\
Mo steel & 14 & $3.05 \mathrm{E}-08$ & 0.883 & 214.4 & 0.00957 & 0.267 & 249.8 & 0.0259 \\
& 28 & $1.81 \mathrm{E}-08$ & 0.912 & 262.5 & 0.00312 & 0.304 & 423.3 & - \\
& 42 & $2.38 \mathrm{E}-08$ & 0.867 & 475.1 & 0.00223 & 0.141 & 678.5
\end{tabular}

Table 6 Mass ratio of the rust phases at $42 \mathrm{CCT}$ in $1 \% \mathrm{O}_{2}$ wet-dry acid corrosion (wt\%)

\begin{tabular}{lllllll}
\hline Steels & $\gamma$-FeOOH & $\alpha$-FeOOH & $\mathrm{Fe}_{x} \mathrm{~S}_{y}$ & $\mathrm{~S}$ & $\mathrm{Fe}_{3} \mathrm{O}_{4}$ & Amorphous phase \\
\hline Blank steel & 1.52 & 6.23 & 2.77 & 1.29 & 1.19 & 87.00 \\
W steel & 1.59 & 5.72 & 3.58 & 1.84 & 1.26 & 86.01 \\
Mo steel & 1.42 & 6.16 & 3.26 & 1.94 & 0.89 & 86.33 \\
\hline
\end{tabular}

Table 7 Mass ratio of the rust phases at $42 \mathrm{CCT}$ in 5\% $\mathrm{O}_{2}$ wet-dry acid corrosion (wt\%)

\begin{tabular}{|c|c|c|c|c|c|c|}
\hline Steels & $\gamma$-FeOOH & $\alpha-\mathrm{FeOOH}$ & $\mathrm{Fe}_{x} \mathrm{~S}_{y}$ & $S$ & $\mathrm{Fe}_{3} \mathrm{O}_{4}$ & Amorphous phase \\
\hline Blank steel & 0.72 & 3.30 & 1.58 & 0.43 & 0.77 & 93.96 \\
\hline W steel & 0.58 & 3.22 & 2.15 & 0.64 & 0.75 & 91.40 \\
\hline Mo steel & 0.72 & 3.70 & 2.06 & 0.72 & 0.66 & 92.76 \\
\hline
\end{tabular}

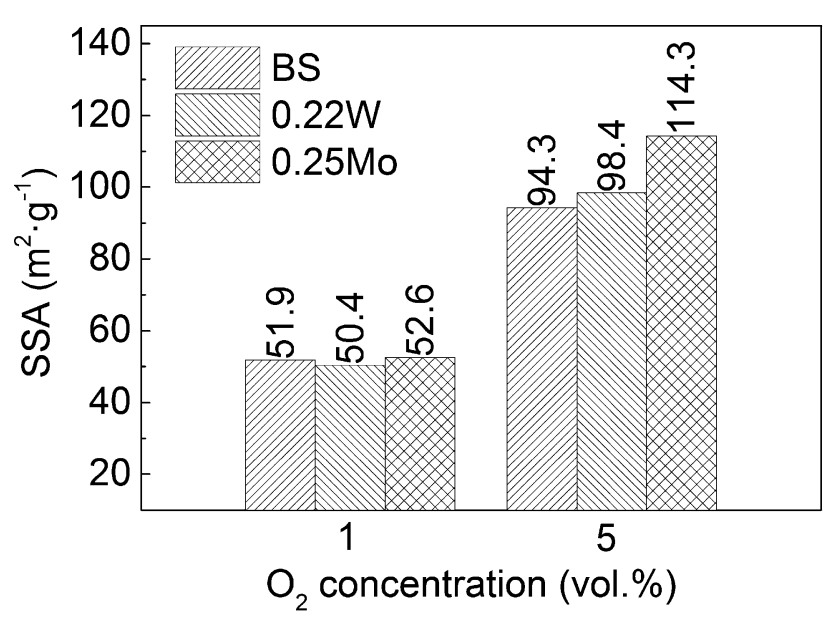

Fig. 10 SSA of the rust at $42 \mathrm{CCT}$ in wet-dry acid corrosion with $\mathrm{O}_{2}$ concentrations of a $1 \%$; b $5 \%$

Figure 12 shows the distribution of the elements $\mathrm{W}$ and Mo in the rusts after $42 \mathrm{CCT}$ under $\mathrm{O}_{2}$ concentrations of both 1 and $5 \%$. Figure $12 \mathrm{a}$ and $\mathrm{b}$ shows that the elements $\mathrm{W}$ and Mo uniformly distribute in the rust under $\mathrm{O}_{2}$ concentration of $1 \%$, while Fig. $12 \mathrm{c}$ and d presents that $\mathrm{W}$ and Mo are enriched in inner layer of the rust under $\mathrm{O}_{2}$ concentration of $5 \%$. The results indicated that the existence of $\mathrm{W}$ and $\mathrm{Mo}$ in the rust was greatly influenced by $\mathrm{O}_{2}$ concentration, and higher $\mathrm{O}_{2}$ concentration promoted the enrichment of elements $\mathrm{W}$ and $\mathrm{Mo}$ in inner layer of the rust.

\section{Discussion}

The phenomenon most deserving of attention in this study was that the elements $\mathrm{W}$ and Mo had different enhanced effects on corrosion resistance of the steels under $\mathrm{O}_{2}$ concentrations of both 1 and 5\%. The obtained results reflected the interaction between the alloying elements $\mathrm{W}$ and $\mathrm{Mo}$ and $\mathrm{O}_{2}$ on the wet-dry acid corrosion behavior of the low-alloy steels. W and Mo additions changed the electrochemical property of the bare steel, and then changed the characteristics of the rust formed on the steel surface.

$\mathrm{W}$ and Mo influenced electrochemical property of the bare steel through solid solution in ferrite [9, 10]. W increased $R_{\mathrm{ct}}$ and decreased $i_{\text {corr }}$ of the bare steel, while Mo decreased $R_{\text {ct }}$ and increased $i_{\text {corr }}$ of the bare steel in acid 

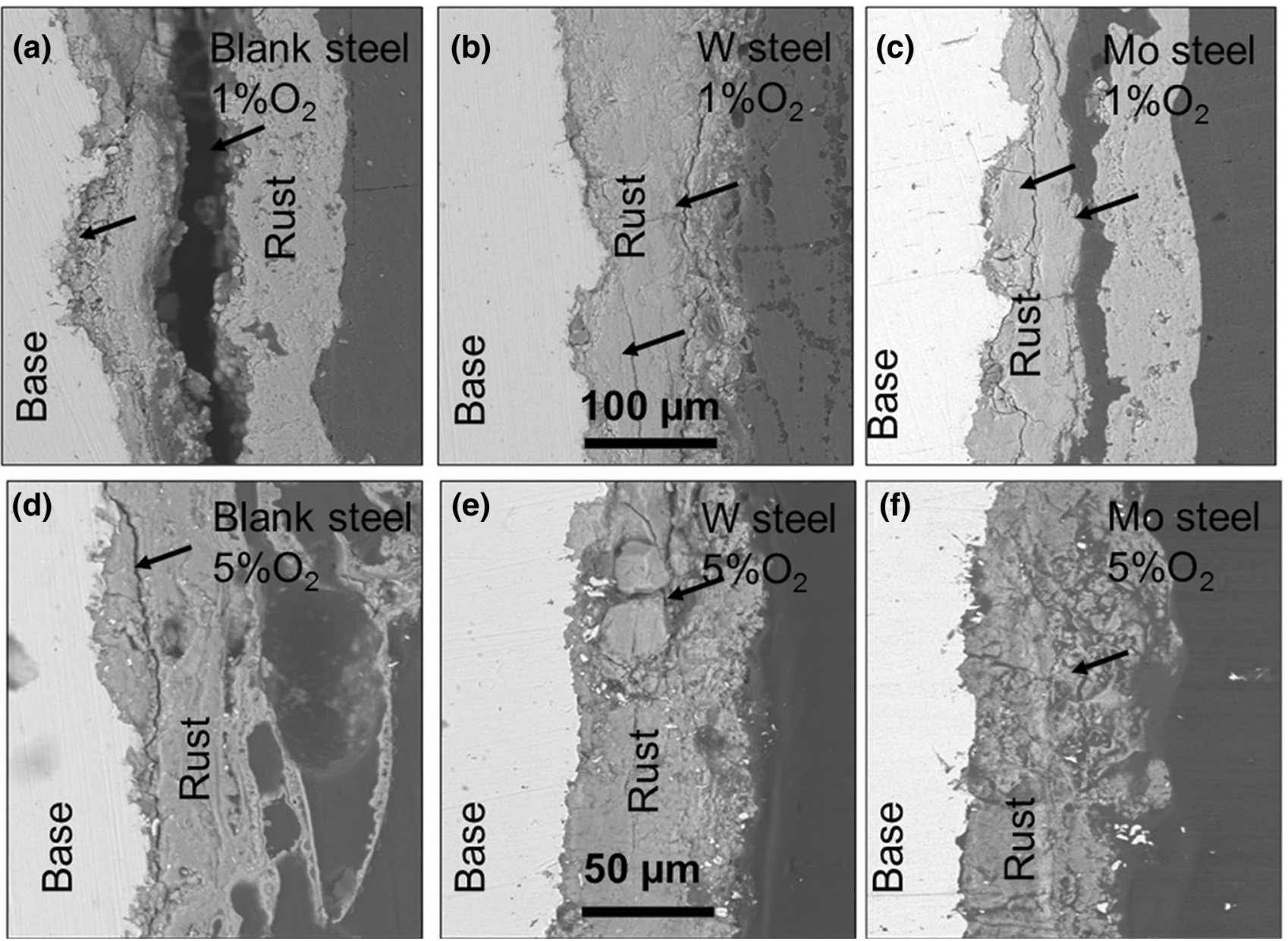

Fig. 11 Cross-sectional morphologies of the rusts at $42 \mathrm{CCT}$ in wet-dry acid corrosion: a-c for the blank steel, $\mathrm{W}$ steel, and $\mathrm{Mo}$ steel under $\mathrm{O}_{2}$ concentration of $1 \%$; $\mathbf{d}-\mathbf{f}$ for the blank steel, W steel, and Mo steel under $\mathrm{O}_{2}$ concentration of $5 \%$

electrolyte, which indicated that $\mathrm{W}$ could depress the dissolution process of the bare steel, while Mo presented an opposite effect. When polarization potential of the steel was more positive than $-0.35 \mathrm{~V}_{\mathrm{SCE}}$, both $\mathrm{W}$ and Mo could depress dissolution process of the bare steel, and the depression effect of $\mathrm{W}$ was higher than that of Mo. Meanwhile, W and Mo could reduce the content of pearlite, and decrease the grain size of ferrite of the steel, as shown in Fig. 2. Homogeneous microstructure of $\mathrm{W}$ and Mocontaining steels could reduce the selective corrosion around pearlite with large grain size [28, 29], which resulted in the more even rust/substrate interface, as shown in Fig. 11.

Elements $\mathrm{W}$ and Mo affected the characteristic of the rust under $\mathrm{O}_{2}$ concentrations of both 1 and $5 \%$. The rust formed under $\mathrm{O}_{2}$ concentration of $1 \%$ was loose and less protective with double-layer structure, while the rust formed under $\mathrm{O}_{2}$ concentration of $5 \%$ was dense and compact with single-layer structure, as shown in Fig. 11. The different characteristics of the rust under $\mathrm{O}_{2}$ concentrations of 1 and $5 \%$ were mainly caused by the different rust compositions, as shown in Tables 6 and 7. The rust under $\mathrm{O}_{2}$ concentration of $5 \%$ contained higher content of amorphous phase, and lower content of $\gamma-\mathrm{FeOOH}, \alpha-$ $\mathrm{FeOOH}, \mathrm{Fe}_{x} \mathrm{~S}_{y}, \mathrm{~S}$ and $\mathrm{Fe}_{3} \mathrm{O}_{4}$ than that under $\mathrm{O}_{2}$ concentration of $1 \%$. Amorphous phase was the main component of dense and protective rust in atmospheric corrosion [30]. Higher content of amorphous phase in the rust under $\mathrm{O}_{2}$ concentration of $5 \%$ contributed to the enhanced rust compactness, as well as higher corrosion resistance of the rusted steel, comparing with that under $\mathrm{O}_{2}$ concentration of $1 \%$.

The enhanced effect of $\mathrm{W}$ on corrosion resistance of the steels was better than that of Mo under $\mathrm{O}_{2}$ concentration of $1 \%$, as shown in Fig. 3a. W was more effective on increasing $R_{\mathrm{ct}}$ of the steel than Mo. Mo had better enhanced effect on corrosion resistance of the steel than $\mathrm{W}$ under $\mathrm{O}_{2}$ concentration of 5\%, as shown in Fig. 3b. Mo had higher promotion effect on increasing both $R_{\text {rust }}$ and $R_{\mathrm{ct}}$, as shown in Tables 4 and 5. The above results indicated that the roles $\mathrm{W}$ and Mo played were greatly influenced by $\mathrm{O}_{2}$ concentration. 


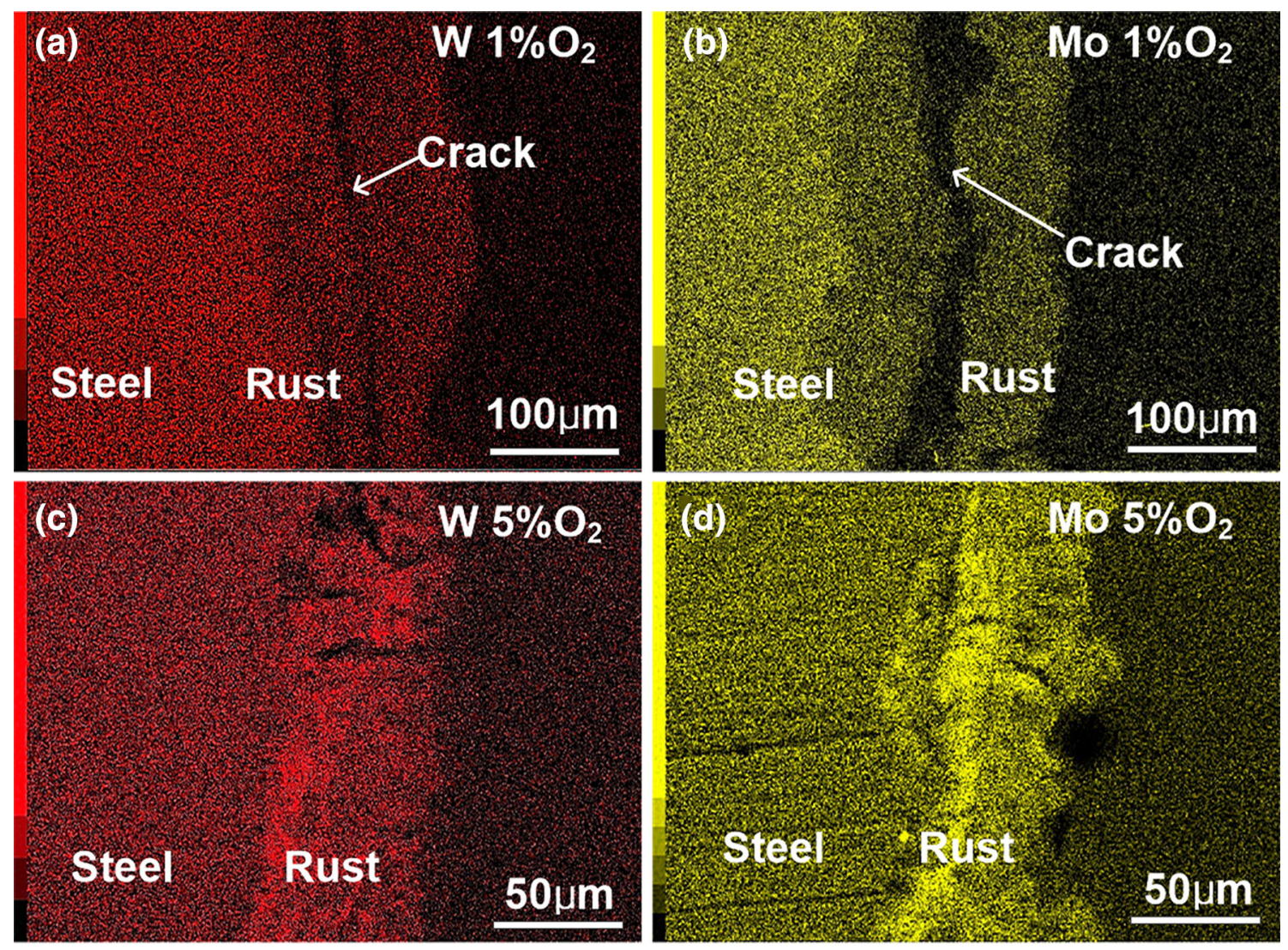

Fig. 12 Distribution of the elements $\mathrm{W}$ and $\mathrm{Mo}$ in the rust at $42 \mathrm{CCT}$ in wet-dry acid corrosion: a W $1 \% \mathrm{O}_{2} ;$ b Mo $1 \% \mathrm{O}_{2} ; \mathbf{c} \mathrm{W}_{1 \%} \mathrm{O}_{2}$; d Mo $5 \%$ $\mathrm{O}_{2}$

Under $\mathrm{O}_{2}$ concentration of $1 \%$, the rust was loose and porous with obvious double-layer structure. The protectiveness of the rust was weak, and W-containing steel presented higher $R_{\mathrm{ct}}$ and identical $R_{\text {rust }}$ comparing with Mo-containing steel, as shown in Table 4. W addition could depress the charge transfer process in the rust/substrate interface, and increase resistance of inner layer of the rust, which improved corrosion resistance of the rusted steel, whereas, under $\mathrm{O}_{2}$ concentration of $5 \%$, the rust was thinner and compacter comparing with that under $\mathrm{O}_{2}$ concentration of $1 \%$. Mo-containing steel presented higher $R_{\mathrm{ct}}$ and $R_{\text {rust }}$ than W-containing steel, as shown in Table 5. Mo addition could increase the rust compactness through forming dense and protective rust, and the enhanced effect of Mo on rust compactness was better than that of W.

\section{Conclusions}

The effects of $\mathrm{W}$ and Mo additions on corrosion behavior of the low-alloy steels in wet-dry acid corrosion with different $\mathrm{O}_{2}$ concentrations were studied, and the conclusions could be summarized as follows:
1. W and Mo-containing steels presented higher corrosion resistance than blank steel under $\mathrm{O}_{2}$ concentrations of both 1 and 5\%. The corrosion behavior of the steels was greatly affected by $\mathrm{O}_{2}$ concentration. $\mathrm{W}$-containing steel presented higher corrosion resistance than Mo-containing steel under $\mathrm{O}_{2}$ concentration of $1 \%$, while Mo-containing steel presented higher corrosion resistance than W-containing steel under $\mathrm{O}_{2}$ concentration of $5 \%$.

2. W addition could depress the metal dissolution of bare steel in acid electrolyte, while Mo presented the opposite effect. Both W and Mo could depress the dissolution of bare steel in acid electrolyte when polarization potential was more positive than -0.35 $\mathrm{V}_{\mathrm{SCE}}$, and the depression effect of $\mathrm{W}$ was better than that of Mo.

3. The rust composition was greatly influenced by $\mathrm{O}_{2}$ concentration. Higher $\mathrm{O}_{2}$ concentration could increase the amount of amorphous phase and decrease the amount of $\gamma$-FeOOH, $\alpha-\mathrm{FeOOH}, \mathrm{Fe}_{x} \mathrm{~S}_{y}, \mathrm{~S}$ and $\mathrm{Fe}_{3} \mathrm{O}_{4}$ in the rust. Higher content of amorphous phase was responsible for the higher rust compactness under $\mathrm{O}_{2}$ concentration of $5 \%$, comparing with that under $\mathrm{O}_{2}$ concentration of $1 \%$. 
4. Rust formed under $\mathrm{O}_{2}$ concentration of $1 \%$ was less protective with double-layer structure, and rust formed under $\mathrm{O}_{2}$ concentration of $5 \%$ was dense and compact with single-layer structure, due to different rust compositions. The enhanced effect of $\mathrm{W}$ on corrosion resistance of the rusted steel under $\mathrm{O}_{2}$ concentration of $1 \%$ was better than that of Mo, because $\mathrm{W}$ was more effective to increase $R_{\mathrm{ct}}$ of the rusted steel than Mo. Mo addition had better enhanced effect on corrosion resistance of the rusted steel than that of $\mathrm{W}$ under $\mathrm{O}_{2}$ concentration of $5 \%$, because Mo had higher promotion effect on increasing both $R_{\text {rust }}$ and $R_{\mathrm{ct}}$ of the rusted steel.

Acknowledgment This work was financially supported by the National Natural Science Foundation of China (No. 51571027).

\section{References}

1. S.A. Park, J.G. Kim, J.B. Yoon, Corrosion 2, 196 (2013)

2. Y.S. Choi, J.J. Shim, J.G. Kim, Mater. Corros. 55, 298 (2004)

3. T. Nishimura, K. Noda, T. Kodama, Corros. Eng. 49, 734 (2000)

4. L. Hao, S. Zhang, J. Dong, Corros. Sci. 54, 244 (2012)

5. F. Sun, X. Li, F. Zhang, X. Cheng, C. Zhou, N. Wu, Y. Yin, J. Zhao, Acta Metall. Sin. (Engl. Lett.) 26, 257 (2013)

6. L. Hao, S. Zhang, J. Dong, Corros. Sci. 3, 270 (2012)

7. T. Misawa, K. Asami, K. Hashimoto, S. Shimodaira, Corros. Sci. 14, 279 (1974)

8. J.W.J. Silva, E.N. Codaro, R.Z. Nakazato, Appl. Surf. Sci. 252, $1117(2005)$

9. S. Kazuhiko, K. Tsutomu, H. Toshiyuki, Corrosion-resistant Steel Material for Ship and Vessel, EP patent, No. 1990437, 2008
10. A. Usami, K. Katoh, T. Hasegawa, A. Shishibori, Crude Oil tank Fabricated from Steel Plate, US patent, No. 7875130, 2011

11. Yasuto, S. Kazuhuko, K. Tsutomu, N. Kimihiro, Corrosion Resistant Steel for Crude Oil Tank, Manufacturing Method Therefor, and Crude Oil Tank, EP patent, No. 2395120, 2011

12. U. Akira, K. Kenji, H. Toshiei, S. Akira, Crude Oil Tank and Method for Producting a Steel for a Crude Oil Tank, EP patent, No. 1516938, 2013

13. X. Hao, J. Dong, J. Wei, W. Ke, C. Wang, X. Xu, Acta Metall. Sin. (in Chinese) 48, 534 (2012)

14. Q. Zhao, W. Liu, J. Zhao, D. Zhang, P. Liu, M. Lu, Int. J. Miner. Metall. Mater. 22, 829 (2015)

15. C.G. Soares, Y. Garbatov, A. Zayed, Corros. Sci. 11, 3095 (2008)

16. J. Guo, G. Wang, L. Ivanov, Mar. Struct. 21, 402 (2008)

17. Z.G. Liu, X.H. Gao, C. Yu, L.X. Du, J.P. Li, P.J. Hao, Acta Metall. Sin. (Engl. Lett.) 28, 739 (2015)

18. T. Kamimura, S. Hara, H. Miyuki, Corros. Sci. 48, 2799 (2006)

19. Q. Guo, J.H. Liu, M. Yu, S.M. Li, Acta Metall. Sin. (Engl. Lett.) 28, 139 (2015)

20. M. Sun, M. Luo, C. Lu, J. Li, Acta Metall. Sin. (Engl. Lett.) 28, 1089 (2015)

21. F.L. Sun, X.G. Li, X.Q. Cheng, Acta Metall. Sin. (Engl. Lett.) 27, 115 (2014)

22. J.O. Bockris, D. Drazic, A.R. Despic, Electrochim. Acta 4, 325 (1961)

23. T.L. Liu, L.J. Chen, H.Y. Bi, X. Che, Acta Metall. Sin. (Engl. Lett.) 27, 452 (2014)

24. L. Hao, S. Zhang, J. Dong, W. Ke, Corros. Sci. 59, 270 (2012)

25. T. Ishikawa, R. Tanaka, M. Minamigawa, K. Kandori, H. Tanaka, T. Nakayama, Mater. Corros. 66, 1460 (2015)

26. T. Ishikawa, T. Yoshida, K. Kandori, T. Nakayama, S. Hara, Corros. Sci. 49, 1468 (2007)

27. H. Tamura, Corros. Sci. 50, 1872 (2008)

28. K. Aasmi, M. Kikuchi, Corros. Sci. 45, 2671 (2003)

29. J. Guo, S. Yang, C. Shang, Y. Wang, X. He, Corros. Sci. 51, 242 (2008)

30. D.A. López, W.H. Schreiner, S.R.D. Sánchez, Appl. Surf. Sci. 207, 69 (2003) 